\title{
Fungal Bioactive Compounds with Antiviral Effect
}

\author{
Tamara Teplyakova and Tatiana Kosogova \\ State Research Center of Virology and Biotechnology Vector, Koltsovo, Novosibirsk Region 630559, Russia
}

\begin{abstract}
Basidial fungi have long been known as sources of antitumor compounds such as polysaccharides. Studies conducted by scientists from different countries demonstrate that polysaccharides and other fungal compounds (proteins, glycoproteins, terpenoids, melanins, nucleosides, etc.) exhibit antiviral activity against many viruses pathogenic for humans. The review presents data on the studied antiviral activities of higher basidial fungi against herpes, West Nile, influenza, human immunodeficiency and hepatitis viruses as well as orthopoxviruses including variola virus. Many species of basidial fungi and various classes of biologically active compounds obtained from them are capable of effectively inhibiting the development of viruses in cells and animals while possessing low toxicity. Biologically active compounds from the same fungal species can exhibit antiviral effects against different pathogens. Effective strains isolated from wild mushrooms in culture represent promising objects for the development of biotechnological drugs, including ones possessing antiviral activity. The data on antitumor and antiviral activities of compounds from the same fungal species indicate the correlation of these properties. In this connection, preparations of basidial fungi may have prophylactic value in preventing cancers of viral etiology.
\end{abstract}

Key words: Biologically active compounds, basidial fungi, pathogenic viruses, antiviral activity.

\section{Introduction}

One of the first scientific publications on fungal medicinal compounds appeared in 1968-1969 and contained the results of investigation of anticancer activity of aqueous extracts obtained from fruiting bodies of wood-destroying fungi Ganoderma lucidum (Curtis) P. Karst. (lacquered polypore, reishi), Lentinus edodes (Berk.) Singer (= Lentinula edodes (Berk.) Pegler) (shiitake), Inonotus obliquus (Ach. ex Pers.) Pilat (chaga), etc., against cancerous tumors grafted to animals such as Sarcoma-180 [1, 2]. These compounds were polysaccharides (glycans), high-molecular compounds from the class of carbohydrates [3]. The first drugs derived from fungi were polysaccharides. The best known of them are lentinan (from shiitake Lentinula edodes, PSP (polysaccharopeptide) and PSK (polysaccharide krestin) (from Trametes versicolor (L.) Lloyd), ganoderan from Ganoderma lucidum, plevran (from common oyster mushroom Pleurotus ostreatus (Jacq.) P. Kumm.), grifolan (from grifola curly Grifola

Corresponding author: Tamara Teplyakova, Ph.D., professor, research fields: mycology, medicinal mushrooms, biotechnology. E-mail: teplyakova@ vector.nsc.ru. frondosa (Dicks.) Gray). They possessed antitumor and immunomodulatory properties $[4,5]$.

Later it was found that polysaccharides and other basidiomycete compounds could have an antiviral effect [6-8].

In recent years, the negative role of viral diseases has increased, and new types of viral infections have emerged. The problem of development of new antivirals has become increasingly acute.

Literature data show that many fungal species and different classes of biological compounds derived from them are capable of inhibiting the development of viruses that are pathogenic for humans. This makes it possible to develop more effective drugs on a complex basis affecting different stages of virus reproduction. The selection of effective strains producing biologically active compounds, which can be used as a basis to design antivirals, is very important for developing a biotechnology for drug production on the basis of fungi. The review presents data obtained by scientists from different countries on antiviral properties of aqueous extracts and some compounds of basidiomycetes with respect to viruses that are most 
pathogenic for humans.

\section{Biologically Active Compounds of Basidial Fungi and Their Efficacies against Some Viruses Pathogenic for Humans}

\subsection{Herpesvirus}

Herpesvirus infections are spread worldwide. HSV-2 (herpes simplex virus type 2) most frequently causes genital herpetic infection $[9,10]$.

Genital herpes incidence in different countries reaches the level of 80-200 cases per 100 thousand of population [11].

HSV-2 is especially dangerous for immunodeficient patients as it causes generalized herpetic infection with extensive lesions of internal organs, often with fatal outcome. A number of antivirals are used to treat herpesvirus infections, acyclovir (zovirax, virolex), a synthetic analogue of deoxy-guanidine, being most frequently used. It can block viral DNA polymerase and viral DNA synthesis after phosphorylation [12]. Its widespread use has led to the emergence of drug-resistant strains of herpesvirus. Toxicity of acyclovir also imposes restrictions on its use in patients with impaired renal function. Other chemicals (idoxuridine, foscarnet, tromantadine), interferons and their inducers as well as drugs of vegetable origin, for example, panavir are also used in medical practice for therapy of herpesvirus infections [13]. However, these tools are not effective in controlling herpesvirus infection [11], therefore, the research and development of new antivirals against HSV-1 and HSV-2 are very urgent.

The study of the composition of the aqueous and methanol extracts of lacquered polypore, Ganoderma lucidum, which significantly inhibited the cytopathic effect of herpes simplex virus, shows that their main components are polysaccharides $(40.6 \%)$ and protein $(7.8 \%)$ associated with them $[14,15]$. It was found that glycoprotein extracted from mycelium of G. lucidum inhibited the cytopathic action of HSV-1 and HSV-2 without any noticeable cytotoxic effect even at a significant concentration of fungal glycoprotein [16].

It was found that Lentinus edodes (shiitake mushroom) extract at the concentration of $0.3 \mathrm{mg} / \mathrm{mL}$ completely inhibited the release of virions of herpes simplex virus type 1 from Vero cells with infectious virus titer of $2.0 \times 10^{4} \mathrm{PFU} / \mathrm{ml}$ [17]. Electron microscopy demonstrated the presence of nucleocapsids outside the nucleus in both control and infected cells treated with the mushroom extract. The authors suggest that the active ingredients of the extract of the fungus Lentinus edodes affect the virus itself or the cellular mechanisms associated with viral replication, which leads to the formation of defective viral particles.

It has been found that sulfated polysaccharides are good candidates for the search of new drugs to treat herpetic infections. The chemically MI-S (modified polysaccharide) extracted from mycelium of Agaricus brasiliensis (= Agaricus blazei Murill) exhibited a promising inhibitory activity against HSV-1 (KOS and 29R (acyclovir-resistant) strains) and HSV-2 strain 333 with a selectivity index ( $\mathrm{SI}=\mathrm{D} / \mathrm{IC} 50)$ higher than 439, 208,562 , respectively. It is noted that MI-S had no virucidal effects, but inhibited the attachment and penetration of HSV-1 and HSV-2 into cells and reduced the expression of HSV-1 proteins ICP27, UL42, gB and gD. The modified polysaccharide MI-S showed synergistic antiviral effect with acyclovir. These results indicate that MI-S can implement several mechanisms of antiherpetic action [18].

A nucleoside was isolated from the culture medium of the fungus Macrocystidia cucumis (Pers.) Joss after fungal culture reached the stationary phase of growth. The isolated purine nucleoside showed efficacy against HSV-1 [19].

A large group of fungal biologically active substances are polypeptides, including ones possessing antiviral activity. From an aqueous extract of the fungus Rozites caperatus (Pers.) P. Karst. (= Cortinarius caperatus (Pers.) Fr.), Frank pirano isolated a new protein-based antiviral drug hindering the processes of replication of 
HSV-1 and HSV-2, cytomegaloviruses, respiratory sincytial virus and influenza virus type A [20]. Antiviral protein $\mathrm{RC} 28$ with antiherpetic activity was derived from the extract of R. caperatus and precipitated with acetone followed by gel filtration and ion-exchange chromatography. RC28 drug inhibits the replication of HSV-1 in vitro at the concentration of $0.078 \mathrm{mg} / \mathrm{mL}$ (IC50) and the therapeutic index (selectivity index) higher than 32. The full-length peptide chain of the antiviral protein from RC28 R. caperatus has 235 amino acid residues, and it does not belong to any known protein family [21].

An agent inhibiting the HSV-1 replication was isolated from the extract of fruiting body of maitake mushroom Grifola frondosa (Dicks.) Gray. The mass spectrometry method was employed to characterize the chemical composition of the protein, and this peptide was found to consist of 11 amino acids [22].

Protein fractions obtained from biomass of the deep culture of the basidiomycete Daedaleopsis confragosa inhibited herpes simplex virus type 2 (IC50 = 0.03-0.06 mg/mL) [23].

Extracts of 10 from 121 species of basidial fungi tested in France for the presence of antiviral activity proved to be active against herpes simplex virus. Extracts of the following species were active against HSV-1: Trametes gibbosa (Pers.) Fr. (1.0-2.25 $\mathrm{mg} / \mathrm{mL})$; Tricholoma virgatum (Fr.) P. Kumm. (1.0 $\mathrm{mg} / \mathrm{mL}$ ); Tricholoma portentosum (Fr.) Quél. $(0.75-2.25 \mathrm{mg} / \mathrm{mL})$; Cortinarius orellanoides Rob. Henry (= Cortinarius rubellus Cooke $)$ (1.5-3.0 $\mathrm{mg} / \mathrm{mL}$ ); Cortinarius sanguineus (Wulfen) Fr. (0.5-1.75 mg/mL); Lactarius torminosus (Schaeff.) Gray (1.25-4.5 $\mathrm{mg} / \mathrm{mL})$. HSV-2 activity was suppressed by Trametes gibbosa $(1.0-2.5 \mathrm{mg} / \mathrm{mL})$; Tricholoma virgatum $(1.0-2.5 \mathrm{mg} / \mathrm{mL})$, T. portentosum (0.5-2.25 mg/mL); T. acerbum (Bull.) Vent. (0.5-2.0 $\mathrm{mg} / \mathrm{mL}$ ); Collybia maculata (Alb. and Schwein.) $P$. Kumm. (= Rhodocollybia maculata (Alb. and Schwein.) Singer) $\quad(0.25-2.0 \quad \mathrm{mg} / \mathrm{mL}) ; \quad$ Rozites caperatus (0.25-2.25 mg/mL); Cortinarius sanguineus (1.75-3.0 $\mathrm{mg} / \mathrm{mL}$ ); Hypholoma fasciculare (Huds.) P. Kumm. (1.0-2.5 mg/mL); H. sublateritium (Schaeff.) Quél. (= H. lateritium (Schaeff.) P. Kumm.) (0.25-2.0 mg/mL); Lactarius torminosus $(1.25 \mathrm{mg} / \mathrm{mL})$ [24].

Belarusian scientists present data on carotenoids isolated from sulfur-yellow Laetiporus sulphureus possessing activity against HSV-1 [25, 26].

Aqueous extracts and polysaccharides of fungi of the genus Pleurotus ( $P$. ostreatus and $P$. pulmonarius) were active against HSV-2. It was found that the antiviral effect of the total fungal polysaccharide fractions was higher than that of the original aqueous extracts. Antiviral activity of aqueous extracts of fungi seems to be associated with the presence of polysaccharides and to increase with their increasing concentrations in the original material or the concentration degree of the total polysaccharide fraction [27]. By the example of the tiered tooth fungus Hericium cirrhatum, it was confirmed that polysaccharide concentration increased antiviral activity against HSV-2. To isolate polysaccharides, basidiomycete biomass obtained by 7-day deep cultivation was homogenized in distilled water in the ratio 1:5. The mixture was kept on a water bath at $60 \pm$ $2{ }^{\circ} \mathrm{C}$ for 2 hours followed by centrifugation at 10,000 $\mathrm{rpm} / \mathrm{min}$ at room temperature for $20 \mathrm{~min}$. The resulting supernatant was treated stepwise with ethanol as follows: 1 from 0 to $30 \%$; $2-30-50 \%$; $3-50-60 \%$; $4-60-70 \% ; 5-70-80 \%$ saturation. In the isolation of total polysaccharides (0-82\% ethanol saturation), the supernatant was mixed with $96 \%$ ethanol in the ratio 1:5. The fraction sediment was formed at the temperature of $4 \pm 2{ }^{\circ} \mathrm{C}$ overnight. The resulting precipitates were separated by centrifugation at 10,000 $\mathrm{rpm} / \mathrm{min}$ at room temperature for $20 \mathrm{~min}$ and subsequently dissolved in distilled water. The resulting solutions were stored at minus $30 \pm 2{ }^{\circ} \mathrm{C}$ until examined [28]. The largest yield of polysaccharides was observed in the second variant with ethanol saturation from $30 \%$ to $50 \%(5.05 \pm 0.8 \mathrm{mg} / \mathrm{ml})$. This variant also showed the highest antiviral activity, and 
its SI (selectivity index) was 148 while that of the aqueous extract was 19 and that of the total polysaccharides was 24 . Thus, $30-50 \%$ ethanol saturation is promising for the extraction of polysaccharides from $H$. cirrhatum [29].

The performed screening of the total polysaccharides from 10 strains of basidiomycetes of the genera Trametes, Pleurotus, Daedaleopsis, Ganoderma, Fomitopsis, Piptoporus with respect to HSV-2 showed promise in deriving polysaccharides of the following fungal strains: Trametes pubescens C-10-01 (SI > 68.6); T. versicolor K-09-01 (SI > 11.3); T. gibbosa K-114 (SI > 74.2); Fomitopsis pinicola $\mathrm{P}-8$ $(\mathrm{SI}=8.00)$. In productivity assessment, the same strains showed a high growth factor, which is important for fungal biomass production in a fermenter [30].

It has been shown that aqueous solution of melanin from natural raw material, chaga Inonotus obliquus at the concentration of $0.006 \mathrm{mg} / \mathrm{mL}$ has $100 \%$ activity against HSV-2 in Vero. cell culture [31]. Melanin derived from the deep culture of I. obliquus fungus strain F-1244, also showed virucidal effect against HSV-2 at the concentration of $\mathrm{IC}_{50}=0.005 \mathrm{mg} / \mathrm{mL}$ (SI $=878$ ), which confirms that melanin production with biotechnological method is promising. It was found that by adding copper ions in the nutrient medium it's possible to induce melanin synthesis in I. obliquus F-1244 culture, which can significantly (by 5 times) increase the yield of melanins. However, it turned out that melanins obtained in the presence of copper ions were less active $\mathrm{IC}_{50}=0.06 \mathrm{mg} / \mathrm{mL}(\mathrm{IS}=38$ ) against herpes simplex virus type 2 . We can assume that the addition of copper, stimulating the functioning of laccase, shifts the dynamic equilibrium point in the work of the enzyme complex, which results in certain changes in the final structure of melanins. Thus, the observed decrease in melanin activity might be the result of modification of their structure, which, in turn, is caused by hyperstimulation of laccase enzyme with copper ions [32].

The protective activity of fungal aqueous extracts was determined using the intraperitoneal route of administration 24 hours before infecting animals with HSV-2. By administering aqueous extracts of fungal species L. edodes and P. ostreatus at the dose of $0.4 \mathrm{mg}$ of dry matter per mouse a day before infecting animals with one $\mathrm{LD}_{50}$ (the virus lethal dose causing the death of 50\% of animals) of HSV-2, 100\% and 90\% survival of animals was detected by administering extracts of fungal species I. obliquus and Hydnellum compactum (Pers.) P. Karst. at the doses of 2 and $0.55 \mathrm{mg}$ of dry matter per mouse, respectively [33].

Experiments on outbred albino mice revealed that an aqueous extract of natural chaga and melanin derived from it at intraperitoneal administration to mice one day before challenge with herpes simplex virus type 2 protected 90 and $88 \%$ of animals from infection, respectively [34].

\subsection{West Nile Virus}

West Nile virus is a typical representative of the family Flaviviridae. The genus Flavivirus includes 53 viral species and most of them cause severe diseases in domestic animals and humans. The most significant infectious diseases from medical point of view are associated with dengue viruses, Japanese encephalitis, tick-borne encephalitis, West Nile and yellow fever viruses.

As shown in experiments with West Nile virus, a-glucans isolated from $L$. edodes, can increase the resistance of animals (mice) to pathogens [35].

Extracts and total polysaccharide fractions obtained from aqueous extracts of fungi belonging to the genera Ganoderma, Lentinus, Pleurotus, Daedaleopsis, Trametes, Laetiporus, Inonotus fully suppressed infectious activity of not less than $1,000 \mathrm{TCID}_{50}$ of West Nile virus [27, 36].

\subsection{Influenza Virus}

Influenza virus is the most famous and common of more than one hundred viruses that cause infectious diseases of the upper respiratory tract. Influenza 
epidemics annually cause 3.5 million cases of severe illness and 300-500 thousand deaths in the world [37].

New epidemic strains of influenza a virus emerge every 1-2 years as a result of point mutations in two surface glycoproteins-HA (hemagglutinin) and NA (neuraminidase). Influenza virus can circumvent the protective mechanisms of human immune system, and therefore, long-term immunity against influenza is not formed. Influenza pandemics causing huge population mortality can cover entire continents [38]. The search for new effective preventive and therapeutic drugs against influenza is one of priority tasks of public health.

Fungal compounds producing an inhibitory effect on influenza virus are known. A substance of protein nature preventing the replication of influenza virus type A was isolated from an aqueous extract of Rozites caperatus fungus [20].

The analysis of antiviral activity of the extract of Ganoderma pfeifferi against influenza virus type A and HSV-1 revealed that the major antiviral component of the extract were triterpenoids: ganodermadiol, lucidodiol and aplanoxin acid G [39-41].

Hispidin and hispolon, substances having isoprenoid nature and found in the ethanol extract of Inonotus hispidus fungus (Bull.) P. Karst., showed antiviral activity against influenza virus type $\mathrm{A}$ and type $\mathrm{B}$. Both extracts of fruiting bodies and fungal mycelium exhibited antiviral activity [42, 43].

Animal studies have shown that $\alpha$-glucan isolated from $L$. edodes can increase the animals' resistance to pathogens as demonstrated in experiments with influenza virus [44, 45].

Antiviral activity of gasteroid fungi was investigated. According to some authors, vodka-based tincture of gasteromycete Phallus impudicus can serve as a preventive tool before influenza epidemics, and it causes $100 \%$ protection effect in the case of colds [46]. A more detailed study of $P$. impudicus with respect to influenza virus $\mathrm{H} 5 \mathrm{~N} 1$ showed that aqueous extracts from fruiting bodies inhibited viral replication in cells by $5.20 \pm 1.50 \mathrm{lg}$, and those from cultured mycelium by $4.45 \pm 1.60 \lg$ [47].

Aqueous extracts from fruiting bodies of the flat polypore Ganoderma applanatum (neutralization index against subtype H5N1 up to $5.00 \pm 0.15 \mathrm{lg}$; the sulphur yellow polypore Laetiporus sulphureus (5.00 \pm $1.67 \mathrm{lg}$ for $\mathrm{H} 5 \mathrm{~N} 1$ and $6.16 \pm 0.14 \mathrm{lg}$ for $\mathrm{H} 3 \mathrm{~N} 2$ ); sclerotium of chaga mushroom $I$. obliquus with neutralization index for subtype H5N1 of $4.7 \pm 1.2 \mathrm{lg}$; the lung oyster mushroom $P$. pulmonarius $(6.06 \pm 0.18$ $\lg$ for $\mathrm{H} 5 \mathrm{~N} 1$ and $5.73 \pm 0.14 \mathrm{lg}$ for $\mathrm{H} 3 \mathrm{~N} 2$ ) were among also especially active against influenza viruses [48-50]. An aqueous extract of mycelium of the larch polypore Fomitopsis officinalis (Vill.: Fr.) Bond. and Singer was active against influenza virus of different subtypes with neutralization indices $\mathrm{NI}=3.00 \pm 0.11 \lg (\mathrm{H} 5 \mathrm{~N} 1)$, NI $=1.50 \pm 0.25 \mathrm{lg}(\mathrm{H} 3 \mathrm{~N} 2)$. High antiviral activity of aqueous extracts of the rough daedaleopsis Daedaleopsis confragosa against influenza virus subtypes H5N1 $(\mathrm{NI}=2.5 \pm 0.14 \mathrm{lg})$ and H3N2 $(\mathrm{NI}=$ $6.3 \pm 0.07 \mathrm{lg}$ ) was also shown $[51,52]$.

Assessment of anti-influenza activity of chaga mushroom melanin showed that at the same dilution (1:3000) the neutralization index was higher for human influenza virus strain A/Aichi/2/68 (H3N2) as compared with avian influenza virus A/chicken/Kurgan/05/2005 (H5N1) (6.3 lg and $3.0 \mathrm{lg}$, respectively), which is obviously associated with biological characteristics of influenza virus strains [31].

Extracts from the basidiomycetes $G$. applanatum, $L$. sulphureus and I. obliquus were tested with respect to the pandemic influenza virus A/Moscow/226/2009 (H1N1) $v$ on MDCK cell culture and then on laboratory mice [53, 54]. It was revealed that all studied mushroom extracts were low toxic for MDCK cell culture and laboratory animals. It was found that basidiomycete extracts inhibited the reproduction of pandemic influenza virus by 2.6-3.2 $\mathrm{lg}$, which was comparable with the effect of the reference drug Tamiflu ${ }^{\circledR}$ in those experiments (inhibition of the viral 
replication was $2.9 \mathrm{lg}$ ). 4 days after infecting the mice with influenza virus, its concentration in the homogenates of lungs from animals treated with extracts of basidiomycetes $I$. obliquus and $L$. sulphureus was significantly below the control, by 1.83 and $2.00 \mathrm{lg}$, respectively (the daily dose of the extracts was 366.7 and $66.7 \mu \mathrm{g} / \mathrm{g}$ of the mouse bodyweight, respectively); for mice treated with Tamiflu ${ }^{\circledR}$, the decrease in the virus amount was $2.16 \mathrm{lg}$ when compared with the control.

\subsection{Human Immunodeficiency Virus}

The only tool to prevent the development of HIV infection and the disease progression is combination ARV (antiretroviral) therapy.

ARV therapy is aimed at suppressing the replication of human immunodeficiency virus i.e. it is etiotropic therapy of HIV infection. Using ARV drugs we can block HIV replication and reduce the virus concentration in the blood (to undetectable levels). This results in the restoration of CD4 lymphocyte subpopulation (full or partial), which prevents the development, facilitates the course or contributes to the disappearance of opportunistic infections improving the quality of life and increasing life expectancy of HIV-infected patients. In addition, prescribing ARV drugs to HIV-positive pregnant women can significantly reduce the likelihood of vertical transmission.

Despite the large number of currently developed anti-HIV drugs, there is a problem of antiviral therapy effectiveness. The main obstacles to the solution of this problem are the toxicity of drugs [55], high cost of drugs and the capability of HIV-1 to develop resistance to antiviral drugs $[56,57]$.

Therefore, the problem of development of effective and inexpensive antiviral agents producing no toxic effect on humans remains extremely urgent.

Some fungal compounds can exert inhibitory effects on human immunodeficiency virus. It has been shown that polysaccharides from PSK krestin and PSP from
Trametes versicolor can inhibit HIV-1 in vitro. They show immunostimulatory effect, krestin supporting killer cells of the immune system, and the polysaccharide-protein complex inhibiting the attachment of HIV-1 gp120 to CD4 surface receptor and HIV reverse transcriptase activity [7, 58-61].

Velutin and flammulin proteins isolated from the winter mushroom Flammulina velutipes have cytotoxic activity and inactivate ribosomes. Velutin inhibits HIV-1 reverse transcriptase [62].

Protein fractions derived from biomass of the deep culture of the basidial fungus $D$. confragosa showed antiviral activity $\left(\mathrm{IC}_{50}\right)$ against HIV-1 at the concentrations from 0.0025 to $0.004 \mathrm{mg} / \mathrm{mL}$ [23].

Some triterpenes of the fungus Ganoderma lucidum, for example, ganoderic acid B, are active against human immunodeficiency virus type 1 in MT- 4 cell culture [63, 64].

An ubiquitin-like glycoprotein that inhibited the development of human immunodeficiency virus was isolated from the oyster mushroom Pleurotus ostreatus [62]. Positive results were obtained with Grifola frondosa fungus glucans in HIV-infected patients [65, 66].

Chaga preparations exhibited effectiveness against HIV-1 [67].

The extract from mycelial culture of the fungus Fuscoporia obliqua (Ach. ex Pers.) Aoshima (= Inonotus obliquus (Ach. ex Pers.) grown on liquid nutrient medium is known to be used as an active ingredient inhibiting human immunodeficiency virus [68].

The melanin-glucan complex derived from chaga fungus I. obliquus showed the highest activity of the five species of fungi $I$. obliquus, $L$. edodes, $G$. applanatum, Phellinus igniarius, Fomes fomentarius tested by scientists from Belarus and Ukraine with respect to HIV-1 in MT- 4 culture cell. The minimum effective concentration of samples ranged from 0.4 to $10 \mu \mathrm{g} / \mathrm{mL}$ in different experiments [69].

Screening of extracts of different basidiomycete 
species of Western Siberia also demonstrated that chaga extracts possessed the highest antiretroviral activity [70].

Complete inhibition of HIV-1 reproduction in MT-4 cells was demonstrated when adding extracts from natural chaga before and after the virus adsorption; the drug dilution was 1:32000, which made up $0.03 \mu \mathrm{g} / \mathrm{mL}$ of dry matter [71].

Fractions of aqueous and hydroalcoholic extracts of chaga exhibited antiviral properties against HIV-1 at the concentration of $5.0 \mu \mathrm{g} / \mathrm{mL}$ when applied to MT-4 culture simultaneously with the virus [72].

There are also sparse data on the evaluation of antiviral activity of melanin. It was found that water-soluble melanin synthesized from heteropolymers, which is produced as a commercial product (Sigma Chemical Co, USA) could inhibit human immunodeficiency virus replication in cell culture at the doses from 0.2 to $10 \mu \mathrm{g} / \mathrm{mL}$ [73].

Evaluation of antiviral effectiveness of melanins derived from chaga on human MT-4 cell culture infected with HIV-1 showed that chaga melanin is capable of $50 \%$ inhibition of HIV-1 reproduction at the concentration of $1.95 \pm 0.65 \mathrm{mg} / \mathrm{mL}$ [31].

Melanins derived not only from natural chaga mushroom, but also from culture fluid and biomass of the strain I. obliquus F-1244 isolated into the culture show inhibitory effect against HIV-1. The conducted research offers opportunities to create antiretrovirals on the basis of melanin obtained by the biotechnological method [74].

Enhanced immunity is important for HIV-infected people. One of these immunity improving drugs derived from mushrooms is "Immune Assist 24/7" [75]. It consists of extracts and polysaccharides of several fungal species (Agaricus blazei, Cordyceps sinensis (Berk.) Sacc., Grifola frondosa, Coriolus versicolor (L.) Quél. (= Trametes versicolor (L.) Lloyd), Ganoderma lucidum, Lentinula edodes) and is inherently a biologically active food supplement. The impact of "Immune Assist 24/7", an immunomodulator and antiviral agent of natural origin, on $8 \mathrm{HIV}$-infected patients was estimated in the regional hospital Sunyani (Ghana). The patients were given three $800 \mathrm{mg}$ tablets of "Immune Assist 24/7" once a day (2.4 g/day); peripheral blood was collected at baseline, Day 30 and Day 60 for CD4+. The study has shown that "Immune Assist 24/7" can be used as the sole therapeutic agent without additional antiretroviral drugs. The number of CD4+ T-lymphocytes significantly increased in all the patients. According to the authors, these initial results are promising and indicate the potential value of further studies of this drug with respect to other immune parameters and viral load in HIV-infected patients.

\subsection{Orthopoxviruses}

The family Poxviridae comprises a large group of viruses, including ones pathogenic for human: variola virus, monkeypox virus, cowpox virus, ectromelia virus, etc.

The eradication of smallpox as a disease is a major victory of public health. Smallpox vaccination is one of the most ambitious projects in the history of medicine, but the negative side of the cessation of immunization is the lack of population immunity to variola virus. Due to the significant increase in the proportion of population susceptible to smallpox, variola virus is increasingly considered as a possible agent of bioterrorist attacks. To date there are no drugs to treat or prevent smallpox, therefore, the search for new antivirals against variola virus and other orthopoxviruses remains an urgent task. A few studies have been conducted in the world to study antiviral effects of basidiomycetes against orthopoxviruses. Several strains of larch polypore Fomitopsis officinalis were isolated into pure culture in the USA. The inhibitory effect of extracts from fungal biomass was evaluated on poxviruses in cell culture. It was found that one of the strains of $F$. officinalis I showed a high antiviral effect against cowpox virus while another strain of $F$. officinalis IV was effective against vaccinia virus. The author concludes that this fungus can possess 
antiviral activity against other orthopoxviruses [76].

According to the authors of the patent [77], compositions consisting of fungi of the genera Fomitopsis, Piptoporus, Ganoderma can be used for prevention and treatment purposes against various viruses including poxviruses.

In Russia, studies on variola virus strain India-3A as well as the vaccinia virus strain L-IVP stored in the Collection of SRC VB Vector have been conducted. Extracts of chaga exhibited the greatest activity against variola virus. The SI (selectivity index) of one of aqueous extracts was more than 9 , and that of the other was 7.4. Their effectiveness increased when they were used according to the prevention scheme i.e. the extracts were applied to Vero cells a day before the virus inoculation. For example, the selectivity index of chaga aqueous extract increased from 7.4 to 29.8. The selectivity index of an aqueous extract from larch polypore $F$. officinalis was 4 .

A sample of melanin $(S I=12.5)$ derived from $I$. obliquus showed activity against vaccinia virus. Extracts from chaga $(\mathrm{SI}=2)$ and larch polypore $(\mathrm{SI}=2)$ possessed certain antiviral potential [31, 78].

Further studies of chemical metabolites from fungi (F. officinalis, I. obliquus) that inhibit VARV replication can detect compounds with different mechanisms of action, which is relevant for the development of therapeutic drugs against smallpox. It can be supposed that samples from the studied fungal species, which showed antiviral effects against two viruses of the family Poxviridae with entirely different pathogenicities, variola virus and vaccinia virus, can be effective against other orthopoxviruses: monkeypox, ectromelia, cowpox and other viruses.

\subsection{Poliovirus}

Poliovirus (Poliovirus hominis) is an infectious agent that causes polio in humans, belongs to the family Picornaviridae, enterovirus group, which also comprises Coxsackie and ECHO viruses. It exists as 3 independent types (I, II and III), type 1 being most common.

In 2007, antiviral activity of aqueous and ethanolic extracts as well as polysaccharides from the fruiting bodies of Agaricus brasiliensis against poliovirus type 1 was tested. The tested substances showed antiviral activity, it is assumed that the active ingredients act at the initial stage of poliovirus replication [79].

Four species showed activity in investigating antiviral effects of extracts from fresh fruiting bodies of 121 species of basidiomycetes against poliovirus: Clitocybe nebularis (Batsch) P. Kumm. (1.0-5.0 $\mathrm{mg} / \mathrm{mL}$ ), Lepista inversa (Scop.) Pat. (= Lepista flaccida (Sowerby) Pat.) (1.0-4.5 mg/mL), Mycena pura (Pers.) P. Kumm. (1.25-1.75 mg/mL), Lactarius torminosus (Schaeff.) Gray (0.5-2.5 mg/mL). These fungi proved to be active against vesicular stomatitis virus [24].

\subsection{Hepatitis Viruses}

Hepatitis viruses belong to different taxons and differ in biochemical and molecular characteristics, but all these viruses cause hepatitis in humans. Chronic liver diseases, including viral hepatitis $\mathrm{B}$ and $\mathrm{C}$ are among the ten leading causes of human deaths. 170 million people worldwide suffer from hepatitis $\mathrm{C}$ and twice as many (350 million) suffer from hepatitis B. About 2 billion people worldwide are infected with hepatitis B virus. HBV (hepatitis B virus) belongs to Hepadnaviridae, a family of DNA viruses that cause liver diseases in humans and animals.

Basidiomycetes such as Cordyceps sinensis, Grifola frondoza and Lentinus edodes have long been used in Oriental medicine to treat liver diseases. However, the number of scientific studies of antiviral activity of basidiomycete metabolites against hepatitis virus is still very limited. The conducted research allows us to identify two possible directions in using basidiomycetes for hepatitis therapy. First, substances produced by various basidiomycetes have been used as adjuvants in vaccination. The problem is that a DNA 
vaccine can induce CD8 (+) T-cell response, but the level of response is very low in most mammals. In the framework of this direction, it was shown that co-administration of a DNA vaccine against hepatitis and a mushroom (Agaricus blazei Murill) extract enriched with polysaccharides (as an adjuvant) to mice significantly enhanced cellular and humoral immune responses [80].

It was also found that purified lectins of $P$. ostreatus as an adjuvant (1 $\mathrm{mg} / \mathrm{mL})$ also enhanced the immunogenicity of the DNA vaccine against hepatitis B [81]. A synthetic beta-glucan, oligosaccharide, an analogue of the basic subunit of lentinan produced by $L$. edodes, was investigated as an adjuvant. It was shown that beta-glucan enhanced CTL and Th1 responses induced by the DNA vaccine [82].

Fractions of an aqueous extract of I. obliquus were shown to possess virucidal properties with respect to hepatitis $\mathrm{C}$ virus, namely, the ability to reduce infectious properties by 100 times within $10 \mathrm{~min}$. Antiviral properties of fungal extracts manifested themselves at both prophylactic use $(24 \mathrm{~h}$ before infection) and therapeutic use (at the time of infecting pig embryo kidney cells) [83].

\subsection{Other Viruses}

There are data on investigations of other viruses. Triterpenes (lutidinic acids, ganoderic acids, methyl ganoderate F. etc.) isolated from fruiting bodies of white rot fungus G. lucidum inhibited the induction of EBV-EA antigen of Epstein-Barr virus occurring under the effect of 12-O-tetradecanoyl phorbol-13acetate in Raji cell line [84].

Water-soluble preparations of $G$. applanatum exhibit antiviral activity against vesicular stomatitis virus VSV IND (Indiana serotype) [40].

\section{Discussion}

The analysis of the published scientific data on the study of antiviral activities of extracts and some compounds derived from basidiomycetes against a number of viruses that are pathogenic for humans suggests that many species of basidiomycetes and different classes of biologically active compounds derived from them can effectively inhibit the development of viruses in cells and animals while possessing low toxicity. The main biologically active compounds derived from basidiomycetes exhibiting antiviral effects include polysaccharides, proteins, glycoproteins, melanins, terpenoids, nucleosides, etc. The presence of proteins, polysaccharides, triterpenes, carotenoids and flavonoids was revealed in aqueous and ethanol extracts of 20 fungal species growing in Southwestern Siberia [85].

Many polysaccharides recognized as antitumor compounds also exhibit antiviral effects $[6,7,86]$. The data on antitumor and antiviral activities of the same fungal species indicate a correlation between these properties [34]. In this context, the role of preparations derived from basidiomycetes can only increase because, in addition to prevention and treatment of viral infections, polysaccharides and other fungal compounds will contribute to prevention of cancers, which have a viral etiology up to $20 \%$ [87].

Published scientific data also indicate that biologically active compounds from the same fungal species can exhibit antiviral effects against different pathogens. Triterpenoids isolated from fruiting bodies, mycelia and spores of lacquered polypore G. lucidum exhibit antiviral activity against human immunodeficiency virus type 1 , hepatitis B and Epstein-Barr viruses [61, 84, 88].

Ganodermadiol, lucidadiol and applanoxidic acid isolated from Ganoderma pfeifferi show activities against HIV-1, HSV-1 and influenza virus type A [39].

Aqueous extracts and polysaccharides from mushrooms belonging to the genera Ganoderma ( $G$. lucidum), Pleurotus ( $P$. eryngii, $P$. djamor, $P$. ostreatus, P. pulmonarius) and Lentinus (L. edodes) possess antiviral activities against RNA-containing WNV and DNA-containing HSV-2 [27].

This allows us to suggest that the type of viral 
nucleic acid does not play a fundamental role in the mechanism of antiviral actions of these drugs.

According to screening results, antiviral effect was found in 32 of the 59 fungal species isolated for the first time in culture from natural habitats in Western Siberia, and in 10 of these species the effect was observed with respect to 3 or more viruses [34, 89-93].

Aqueous extracts and melanin derived from natural chaga Inonotus obliquus exhibit activity against many viruses: human immunodeficiency type 1 , herpes simplex virus type 2 , West Nile, influenza, vaccinia and monkeypox viruses [31, 34]. This broad spectrum of antiviral activity is associated with complex composition of compounds. The main component of aqueous extracts from chaga is the chromogen-PPC (polyphenol carbon complex) similar to HA (humic acids) in physicochemical characteristics. PPC and HA are complexly organized natural objects with unknown structure. Polyphenol oxicarbon complexes contain a polymer synthesized by the fungus on the basis of lignin. It has irregular structure, and its structural units are esters of sinapyl and coniferyl aldehydes, vanillin, syringaldehyde, syringic, vanillic, n-oxybenzoic gallic and protocatechuic acids and their derivatives [94-97]. The polyphenol complex also includes free and bound phenols and carbohydrates, flavonoids, carbonic acids, etc. Coloring of polyphenols is due to melanins classified under allomelanins [98-100].

New data demonstrate the complexity of chaga composition. Terpenoids, sterols and new sesquiterpene have been detected in sclerotium and mycelium of the fungus [101].

The research results indicate that fungi represent promising objects for the development of biotechnological drugs because both mycelium and fruiting bodies contain all important biologically active compounds [102-107]. The use of deep cultivation to produce mycelium biomass allows for the standardization of conditions for formation of biologically active substances and the final product. An important condition for the development of new effective biotechnology antivirals is the presence of active strains of basidiomycetes producing biologically active substances.

\section{Conclusion}

Basidiomycetous fungi have long been known as sources of anticancer compounds such as polysaccharides. Studies conducted by scientists from different countries have shown that polysaccharides and other fungal compounds (proteins, glycoproteins, terpenoids, nucleosides, etc.) exhibit antiviral activity against many viruses pathogenic for humans: herpes, West Nile, influenza, human immunodeficiency, hepatitis viruses and orthopoxviruses. Biologically active compounds derived from the same fungal species can exhibit antiviral effects against different pathogens. Effective strains isolated in culture from wild mushrooms are objects for the development of drugs including ones possessing antiviral activity on the basis of mycelium biomass and extraction of the necessary BAS from it.

\section{References}

[1] Ikekawa, T., Nakanishi, M., Uehara, N., Chihara, G., and Fukuoka, F. 1968. "Anti-tumor Action of Some Basidiomycetes, Especially Phellinus linteus." Jap. J. Cancer Res. 59: 155-7.

[2] Ikekawa, T., Uehara, N., Maeda, Y., Nakanishi, M., and Fukuoka, F. 1969. "Antitumor Activity of Aqueous Extracts of Edible Mushrooms." Cancer Res. 29: 734-5.

[3] Stacey, M., and Barner, S. 1965. Carbohydrates of Living Yissues. Moscow. (in Russian)

[4] Wasser, S. P. 2002. "Medicinal Mushrooms as a Source of Antitumor and Immunomodulating Polysaccharides." Appl. Microbiol. Biotechnol. 60: 258-74.

[5] Wasser, S. P. 2014. "Medical Mushroom Science, Current Perspectives, Advances, Evidences, and Challenges." Biomed. J. 37: 345-56.

[6] Tochikura, S. 1988. "Inhibition (in Vitro) of Replication and of the Cytopathic Effect of Human Immunodeficiency Virus by an Extract of the Culture Medium of Lentinus edodes Mycelia." Med. Microbiol. Immunol. 177 (5) 235-44.

[7] Collins, R. A., and Ng, T. B. 1997. "Polysaccharopeptide from Trametes versicolor Has Potential for Use against 
Human Immunodeficiency Virus Type 1 Infection." Life Science 60 (25): 383-7.

[8] Polishchuk, O. M., and Kovalenko, O. G. 2009. "Biological Activity of Glycolpolymers of Basidial Fungi." Biopolymers and Cells 25 (3): 181-93. (in Ukrainian)

[9] Weiss, H. 2004. "Epidemiology of Herpes Simplex Virus Type 2 Infection in the Developing World." Herpes 11 (1): 24A-35A.

[10] Malkin, J. E. 2004. "Epidemiology of Genital Herpes Simplex Virus Infection in Developed Countries." Herpes 11 (1): 2A-23A.

[11] Johns, S., and Cunningham, A. 2004. "Vaccine Prophylaxis of Genital and Neonatal Herpes Caused by Herpes Simplex Virus.” Sexually Transmitted Infections 1: 46-9. (in Russian)

[12] Faulds, D., and Heel, R. C. 1990. "Ganciclovir. A Review of Its Antiviral Activity, Pharmacokinetic Properties and Therapeutic Efficacy in Cytomegalovirus Infections.” J. Drugs 39: 59.

[13] Kuzovkova, T. V., Gerasimova, N. M., and Kungurov, N. V. 2002. "The Experience of Using Panavir Drug to Treat Patients with Genital Herpesvirus Infection.” J. Bulletin of Postgraduate Medical Education 3-4: 14-6. (in Russian)

[14] Eo, S. K., Kim, Y. S., Lee, C. K., and Han, S. S. 1999. "Antiherpetic Activities of Various Protein Bound Polysaccharides Isolated from Ganoderma lucidum." Journal of Ethnopharmacology 68 (1-3): 175-81.

[15] Kim, Y. S., Eo, S. K., Oh, K. W., Lee, C., and Han, S. S. 2000. "Antiherpetic Activities of Acidic Protein Bound Polysaccharide Isolated from Ganoderma lucidum Alone and in Combinations with Interferons." Journal of Ethnopharmacology 72 (3): 451-8.

[16] Liu, J., Yang, F., Ye, L., Yang, X., Timani, K., Zheng, Y., and Wang, Y. 2004. "Possible Mode of Action of Antiherpetic Activities of a Proteoglycan Isolated from the Mycelia of Ganoderma lucidum in Vitro." Journal of Ethnopharmacology 95: 265-72.

[17] Sarkar, S., Koga, J., Whitley, R. J., and Chatterjee, S. 1993. "Antiviral Effect of the Extract of Culture Medium of Lentinus edodes Mycelia on the Replication of Herpes Simplex Virus Type 1." Antiviral Research 20 (4): 293-303.

[18] Cardozo, F. T., Camelini, C. M., Mascarello, A., Rossi, M. J., Nunes, R. J., Barardi, C. R., de Mendonça, M. M., and Simões, C. M. 2011. "Antiherpetic Activity of a Sulfated Polysaccharide from Agaricus brasiliensis Mycelia." Antiviral Research 92 (1): 108-14.

[19] Saboulard, D., Gaspar, A., Roussel, B., and Villard, J. 1998. "New Antiherpetic Nucleoside from a Basidiomycete." Comptes Rendus de l'Académie des Sciences-Series III-Sciences de la Vie. 321 (7): 585-91.

[20] Pirano F. F. 2005. "The Development of the Antiviral
Drug RC 28 from Rozites caperata (Pers.: Fr.) P. Karst. (Agaricomycetidae)." International Journal of Medicinal Mushrooms 7: 356.

[21] Gong, M., Pirano, F., Yan, N., Zhang, J., Xia, M., Ma, J., Cheng, J., and Liu, X. 2009. "Purification, Partial Characterization and Molecular Cloning of the Novel Antiviral Protein RC28." Peptides 30 (4): 654-9.

[22] Gu, C., Li, J., Chao, F., Jin, M., Wang, X., and Shen, Z. 2007. "Isolation, Identification and Function of a Novel Anti-HSV-1 Protein from Grifola frondosa." Antiviral Research 75: 250-7.

[23] Gileva, I. P., Bardasheva, A. V., Gashnikova, N. M., Balakhnin, S. M., Kazachinskaya, E. I., Kosogova, T. A., and Teplyakova, T. V. 2014. "Antiviral Proteins from Basidial Fungus Daedaleopsis confragosa." Advances in Medical Mycology 12: 302-3. (in Russian)

[24] Amoros, M., Boustie, J., Py, M.-L., Hervé, V., Robin, V., and Girre, L. 1997. "Antiviral Activity of Homobasidiomycetes: Evaluation of 121 Basidiomycetes Extracts on Four Viruses.” Int. J. Pharmacognosy 35 (4): 255-60.

[25] Kapich, A. N., Gvozdkova, T. S., Kvacheva, Z. B., Nikolaeva, S. N., Shishkina, L. N., Galkin, S., Hatakka, A., Konoplya, E. F., Vereshako, G. G., Hodosovskaya, A. M., and Rutkovskaya, J. A. 2004. "Antioxidant, Radioprotective and Antiviral Properties of Mycelial Extract of the Fungus Laetiporus sulphureus." Advances in Medical Mycology 3: 146. (in Russian)

[26] Kvacheva, Z. B., Kapich, A. N., Votyakov, V. I., and Nikolaeva, S. N. 2005. "Antiviral Activity of Extracts from Mycelium of the Basidial Fungus Laetiporus sulphureus." Advances in Medical Mycology 5: 271-3. (in Russian)

[27] Razumov, I. A., Kosogova, T. A., Kazachinskaya, E. I., Puchkova, L. I., Shcherbakova, N. S., Gorbunova, I. A., Mikhailovskaya, I. N., Loktev, V. B., and Teplyakova, T. V. 2010. "Antiviral Activity of Aqueous Extracts and Polysaccharide Fractions Derived from Mycelium and Fruiting Bodies of Higher Fungi." Antibiotics and Chemotherapy 55 (9-10): 14-8. (in Russian)

[28] Chihara, G., Hamuro, J., Maeda, Y. Y., Arai, Y., and Fukuoka, F. 1970. "Fractionation and Purification of the Polysaccharides with Marked Antitumor Activity, Especially Lentinan, from Lentinus edodes (Berk.) Sing. (An Edible Mushroom)." Cancer Research 30 (11): 2776-81.

[29] Bardasheva, A. V., Ilyicheva, T. N., Durymanov, A. G., and Teplyakova, T. V. 2015. "Antiviral Activity of Polysaccharides of the Tiered Tooth Fungus Hericium cirrhatum Pers. 1794 with Respect to Herpes Simplex Virus Type 2." Advances in Medical Mycology 14: 395-9. (in Russian) 
[30] Bardasheva, A. V., Kosogova, T. A., Ilyicheva, T. N., and Teplyakova, T. V. 2015. "Antiviral Activity of Aqueous Extracts and Total Polysaccharides from Basidiomycetes with Respect to Herpes Simplex Virus Type 2 and Influenza Virus Type A." Advances in Medical Mycology 14: 380-92. (in Russian)

[31] Teplyakova, T. V., Puchkova, L. I., Kosogova, T. A., Bulychev, L. E., Shishkina, L. N., Mazurkova, N. A., Gashnikova, N. M., Balakhnin, S. M., Kabanov, A. S., Kazachinskaya, E. I., and Afonina, V. S. 2013. A Melanin-Based Antiviral Drug. RU Patent 2480227 C2, filed July 01, 2011, and issued April 27, 2013. (in Russian)

[32] Anan'ko, G. G., Teplyakova, T. V., Bardasheva, A. V., and Ilyicheva, T. N. 2015. "Melanins from the Deep Culture of Inonotus obliquus and Their Antiviral Activity with Respect to Herpes Simplex Virus Type 2." Advances in Medical Mycology 14: 384-8. (in Russian)

[33] Razumov, I. A., Kazachinskaya, E. I., Puchkova, L. I., Kosogova, T. A., Gorbunova, I. A., Loktev, V. B., and Teplyakova, T. V. 2013. "Antiviral Activity of Aqueous Extracts from Higher Fungi against Experimental Herpesvirus Infection in Albino Mice." Antibiotics and Chemotherapy 58 (9-10): 8-12. (in Russian)

[34] Teplyakova, T. V., Kosogova, T. A. 2014. Higher Fungi of Western Siberia as Promising Objects for Drug Production Biotechnology. Novosibirsk. (in Russian)

[35] Wang, S., Welte, T., and Fang, H. 2009. "Oral Administration of Active Hexose Correlated Compound Enhances Host Resistance to West Nile Encephalitis in Mice." The Journal of Nutrition 139 (3): 598-602.

[36] Kosogova, T. A. 2013. "Basidiomycete Strains of Southwestern Siberia as Promising Producers of Biologically Active Preparations." Ph.D. thesis in Biology, State Research Center of Virology and Biotecnology Vector. (in Russian)

[37] The WHO Public Health Research Agenda for Influenza. 2009. Accessed March 23, 2014. http://www.who.int/influenza/resources/research/2010_1 1_15_global_influenza_research_agenda_version_01_ru. pdf.

[38] Kamps, B. S., and Reyes-Teran, G. Influenza 2006. In: Kamps, B. S., Hoffman, C., Preiser, W., editors. Influenza Report 2006. Paris, Cagliari, Wuppertal, Sevilla: Flying publisher. 2006: 17-47. Accessed March 23, 2014 http://www.InfluenzaReport.com.

[39] Mothana, R. A. A., Awadh, N. A. A., Jansen, R., Wegner, U., Mentel, R., and Lindequist, U. 2003. "Antiviral Lanostanoid Triterpenes from the Fungus Ganoderma pfeifferi Bres.” Fitoterapia 74 (1-2): 177-80.

[40] Zjawiony, J. K. 2004. "Biologically Active Compounds from Aphyllophorales (Polypore) Fungi.“ J. Nat. Prod. 67 (2): $300-10$
[41] Niedermeyer, T. H. J., Lindequist, U., Mentel, R., Gordes, D., Schmidt, E., Thurow, K., and Lalk, M. 2005. "Antiviral Terpenoid Constituents of Ganoderma pfeifferi." J. Nat. Prod. 68: 1728-31.

[42] Ali, N. A. A., Jansen, R., Pilgrim, H., Liberra, K., and Lindequist, U. 1996. "Hispolon, a Yellow Pigment from Inonotus hispidus." Phytochemistry 41 (3): 927-9.

[43] Ali, N. A. A., Mothana, R. A. A., Lesnau, A., Pilgrim, H., and Lindequist, U. 2003. "Antiviral Activity of Inonotus hispidus." Fitoterapia 74: 483-5.

[44] Ritz, B. W., Nogusa, S., Ackerman, E. A., and Gardner, E. M. 2006. "Supplementation with Active Hexose Correlated Compound Increases the Innate Immune Response of Young Mice to Primary Influenza Infection." The Journal of Nutrition 136 (11): 2868-73.

[45] Nogusa, S., Gerbino, J., and Ritz, B. W. 2009. "Low-Dose Supplementation with Active Hexose Correlated Compound Improves the Immune Response to Acute Influenza Infection in C57BL/6 Mice.” Nutrition Research 29 (2): 139-43.

[46] Babayants, O. V., Bushulyan, M. A., and Zalogina, M. A. 2006. "Phallus impudicus L.: Pers.- - the Prospects of Use in Medicine.” Advances in Medical Mycology 7: 240-2. (in Russian)

[47] Teplyakova, T. V., Kosogova, T. A., Mazurkova, N. A., Makarevich, E. V., and Stavskiy, E. A. 2012. The Inhibitor of Influenza a Virus Reproduction Based on an Extract of the Basidial Fungus Phallus impudicus. RU Patent 2475529 C2. filed March 14, 2011, and issued September 20, 2012. (in Russian)

[48] Kabanov, A. S., Shishkina, L. N., Teplyakova, T. V., Puchkova, L. I., Kosogova, T. A., Mazurkova, N. A., Skarnovich, M. O., and Sergeev, A. N. 2009. "The Study of Antiviral Effectiveness of Extracts from Basidial Fungi with Respect to Avian Influenza Virus." Immunopathology, Allergology, Infectology 2: 185-6. (in Russian)

[49] Kabanov, A. S., Shishkina, L. N., Teplyakova, T. V., Puchkova, L. I., Kosogova, T. A., Mazurkova, N. A., Skarnovich, M. O., and Sergeev, A. N. 2008. "The Study of Antiviral Effectiveness of Extracts from Basidial Fungi with Respect to Avian Influenza Virus." In: Achievements of Modern Biotechnology. Collected Scientific Works edited by I. G. Drozdov, 111-9. (in Russian)

[50] Kabanov, A. S., Kosogova, T. A., Shishkina, L. N., Teplyakova, T. V., Skarnovich, M. O., Mazurkova, N. A., Puchkova, L. I., Malkova, E. M., Stavskiy, E. A., and Drozdov, I. G. 2011. "The Study of Antiviral Effectiveness of Extracts from Basidial Fungi in Experiments in Vitro and in Vivo with Respect to Influenza Virus Strains of Different Subtypes." Journal of Microbiology, Epidemiology and Immunology 1: 40-3. (in 
Russian)

[51] Teplyakova, T. V., Psurtseva, N. V., Kosogova, T. A., Mazurkova, N. A., and Vlasenko, V. A. 2010. "Antiviral Activity of Basidial Fungi of Gorny Altai." In Proceedings of the 9th International Scientific and Practical Conference the Problems of Botany of South Siberia and Mongolia, 25-27. (in Russian)

[52] Teplyakova, T. V., Psurtseva, N. V., Kosogova, T. A., Mazurkova, N. A., Khanin, V. A., and Vlasenko, V. A. 2012. "Antiviral Activity of Polyporoid Mushrooms (Higher Basidiomycetes) from Altai Mountains (Russia)." International Journals for Medicinal Mushrooms 14 (1): $37-45$.

[53] Filippova, E. I., Kabanov, A. S., Skarnovich, M. O., Mazurkov, O. Yu., Teplyakova, T. V., Kosogova, T. A., Makarevich, E. V., Ibragimova, Zh. B., Troshkova, G. P., Shishkina, L. N., and Mazurkova, N. A. 2013. "Extracts from Basidial Fungi Inhibit Replication of Avian Influenza Virus A (H5N1) in Experiments in Vitro and in Vivo." Modern Problems of Science and Education 5. Accessed October 2013. http://www.science-education.ru/111-10250. (in Russian)

[54] Filippova, E. I., Mazurkova, N. A., Kabanov, A. S., Teplyakova, T. V., Ibragimova, Zh. B., Makarevich, E. V., Mazurkov, O. Yu., and Shishkina, L. N. 2013. "Antiviral Properties of Aqueous Extracts Isolated from Higher Basidiomycetes with Respect to Pandemic Influenza Virus (H1N1)2009." Modern Problems of Science and Education 2. (in Russian)

[55] Inouye, M., and Inouye, S. 1991. "MsDNA and Bacterial Reverse Transcriptase." Ann. Rev. Microbiol. 54: 163-86.

[56] Gashnikova, N. M., Bogachev, V. V., Baryshev, P. B., Meshcheryakova, Yu. V., Savochkina, E. B., and Chernousova, N. Ya. 2012. "The Spread of Mutations Responsible for Resistance to Antiretroviral Drugs among HIV-1 Variants Circulating in Novosibirsk Region." Journal of Microbiology, Epidemiology and Immunology 6: 56-60. (in Russian)

[57] Baryshev, P. B., Bogachev, V. V., and Gashnikova, N. M. 2014. HIV-1 Genetic Diversity in Russia: CRF63_02A1, a New HIV Type 1 Genetic Variant Spreading in Siberia." AIDS Res Hum Retroviruses 30: 592-7.

[58] Tochikura, T. S., Nakashima, H., Hirose, K., and Yamamoto, N. 1987. "A Biological Response Modifier, PSK, Inhibits Human Immunodeficiency Virus Infection in Vitro.” Biochem. Biophys. Res. Comm. 148: 726-33.

[59] Lorenzen, K., and Anke, T. 1998. "Basidiomycetes as a Source for New Bioactive Natural Products." Current Organic Chemistry 2: 329-64.

[60] Stamets, P. 2002. MycoMedicinals. An Informational Treatise on Mushrooms. Olympia, WA: MycoMedia Productions.
[61] Mlinaric, A., Kac, J., and Pohleven, F. 2005. "Screening of Selected Wood-Damaging Fungi for the HIV-1 Reverse Transcriptase Inhibitors.” Acta. Pharmacology 55: 69-79.

[62] Wang, H. X. and Ng, T. B. 2001. "Isolation and Characterization of Velutin, a Novel Low-Molecular-Weight Ribosome-Inactivating Protein from Winter Mushroom (Flammulina velutipes) Fruiting Bodies." Life Science 68: 2151-8.

[63] El-Mekkawy, S., Meselhy, M. R., Nakamura, N., Tezuka, Y., Hattori, M., Kakiuchi, N., Shimotohno, K., Kawahata, T., and Otake, T. 1998. "Anti-HIV-1 and Anti-HIV-Protease Substances from Ganoderma lucidum." Phytochemistry 49 (6): 1651-7.

[64] Yang, M., Wang, X., Guan, S., Xia, J., Sun, J., Guo, H., and Guo, D. A. 2007. "Analysis of Triterpenoids in Ganoderma lucidum Using Liquid Chromatography Coupled with Electrospray Ionization Mass Spectrometry.' J. Am. Soc. Mass Spectrom. 18: 927-39.

[65] Wang, H. X., and Ng, T. B. 2000. "Isolation of a Novel Ubiquitin-Like Protein from Pleurotus ostreatus Mushroom with Anti-human Immunodeficiency Virus, Translation-Inhibitory and Ribonuclease Activities." Biochem. Biopnys. Res. Commun. 256: 587-93.

[66] Nanba, H., Kodama, N., Schar, D., and Turner, D. 2000. "Effects of Maitake (Grifola frondosa) Glucan in HIV-infected Patients." Mycoscience 41: 293-5.

[67] Ichimura, T., Watanabe, O., and Maruyama, S. 1998. "Inhibition of HIV-1 Protease by Water-Soluble Lignin-Like Substance from an Edible Mushroom, Fuscoporia oblique." Bioscience, Biotechnology, Biochemistry 62: 575-7.

[68] Clifford, W., Tarek, S., and Ru-Rong, J. Methods for Inhibiting Pain. 2004. US Patent 2004/0105,859, filed December 15, 2003, and issued Jun 3, 2004.

[69] Rytik, P. G., Gorovoy, L. F., Kucherov, I. I., Senyuk, O. F., and Mistryukova, L. O. 2007. "Antiretroviral Activity of Some Species of Higher Basidial Fungi." The Russian Journal “AIDS, Cancer and Public Health" 11 (1): 59-61. (in Russian)

[70] Gashnikova, N. M., Teplyakova, T. V., Pronyaeva, T. R., Puchkova, L. I., Kosogova, T. A., and Sergeev, A. N. 2009. "The Results of the Studies to Reveal Anti-HIV Activity of Extracts from Higher Basidial Fungi." Immunopathology, Allergology, Infectology 2: 170-1. (in Russian)

[71] Teplyakova, T. V., Gashnikova, N. M., Puchkova, L. I., Pronyaeva, T. R., and Kosogova, T. A. 2009. Inhibitor of Reproduction of Human Immunodeficiency Virus Type 1. RU Patent 2375073 C1, filed Jun 11, 2008, and issued December 10, 2009. (in Russian)

[72] Shibnev, V. A., Garaev, T. M., Finogenova, M. P., Kalnina, L. B., and Nosik, D. N. 2015. "Antiviral Activity 
of Aqueous Extracts of the Birch Fungus Inonotus obliquus Against Human Immunodeficiency Virus." Problems of Virology 60 (2): 35-8. (in Russian)

[73] Montefiori, D. C. 1991. Method of Inhibiting Replication of HIV with Water-Soluble Melanins. US Patent 5,057,325, filed March 20, 1990, and issued October 15, 1991.

[74] Gashnikova, N. M., Balakhnin, S. M., Teplyakova, T. V., Anan'ko, G. G., Kosogova, T. A., and Sukhikh, A. S. 2014. "Antiretroviral Activity of Melanins from Natural and Cultivated Chaga (Inonotus obliquus)." Advances in Medical Mycology 12: 299-301. (in Russian)

[75] Adotey, G., Quarcoo, A., Holliday, J. C., Fofie, S., and Saaka, B. 2011. "Effect of Immunomodulating and Antiviral Agent of Medicinal Mushrooms (Immune Assist 24/7) on CD4+ T-lymphocyte cCounts of HIV-Infected Patients.” Int. J. Med. Mushrooms 13 (2): 109-13.

[76] Stamets, P. 2005. "Antipox Properties of Fomitopsis officinalis (Vill.: Fr.) Bond. and Singer (Agaricon) from the Pacific Northwest of North America." Int. J. Med. Mushrooms 7: 495-506.

[77] Stamets, P. Antiviral Activity from Medicinal Mushrooms. US Patent 20060171958, filed March 22, 2006, and issued August 03, 2006.

[78] Teplyakova, T. V., Bulychev, L. E., Kosogova, T. A., Ibragimova, Zh. B., Yurganova, I. A., Kabanov, A. S., Puchkova, L. I., Bormotov, N. I., and Bardasheva, A. V. 2012. "Antiviral Activity of Extracts from Basidial Fungi with Respect to Orthopoxviruses." The Problems of Particularly Dangerous Infections 3 (113): 99-101. (in Russian)

[79] Faccin, L. C., Benati, F., Rincão, V. P, Mantovani, M. S., Soares, S. A., Gonzaga, M. L., Nozawa, C., and Carvalho Linhares, R. E. 2007. "Antiviral Activity of Aqueous and Ethanol Extracts and of an Isolated Polysaccharide from Agaricus brasiliensis against Poliovirus Type 1." Letters in Applied Micribiology 45: 24-8.

[80] Chen, L., Shao, H. J., and Su, Y. B. 2004. "Communization of Agaricus Blazei Murill Extract with Hepatitis B Virus Core Protein through DNA Vaccine Enhances Cellular and Humoral Immune Responses." International Immunopharmacology 4: 403-9.

[81] Gao, W., Sun, Y., Chen, S., Zhang, J., Kang, J., Wang, Y., Wang, H., Xia, G., Liu, Q., and Kang, Y. 2013. "Mushroom Lectin Enhanced Immunogenicity of HBV DNA Vaccine in C57BL/6 and HBsAg-transgenic Mice." Vaccine 31: 2273-80.

[82] Wang, J., Dong, S., Liu, C., Wang, W., Sun, S., Gu, J., Wang, Y., Boraschi, D., and Qu, D. 2010. " $\beta$-Glucan Oligosaccharide Enhances CD8+ $\mathrm{T}$ Cells Immune Response Induced by a DNA Vaccine Encoding Hepatitis B Virus Core Antigen.” J. Biomed. Biotechnol. Accessed
September 21, 2014, http://dx.doi.org/10.1155/2010/645213.

[83] Shibnev, V. A., Mishin, D. V., Garaev, T. M., Finogenova, N. P., Botikov, A. G., and Deryabin, P. G. 2011. "Antiviral Activity of Extracts of the Fungus Inonotus obliquus Against Hepatitis C Virus Infection in Cell Culture." Bulletin of Experimental Biology and Medicine 151 (5): 549-51. (in Russian).

[84] Iwatsuki, K., Akihisa, T., Tokuda, H., Ukiya, M., Oshikubo, M., Kimura, Y., Asano, T., Nomura, A., and Nishino, H. 2003. "Lucidenic Acids P and Q, Methyl Luciderate $\mathrm{P}$, and Other Triterpenoids from Fungus Ganoderma lucidum and Their Inhibitory Effects on Epstein-Barr Virus Activation." J. Nat. Prod. 66 (12): 1582-5.

[85] Kostina, N. E., Ibragimova, Zh. B., Protsenko, M. A., Makarevich, E. V., Skarnovich, M. A., Filippova, E. I., Gorbunova, I. A., Vlasenko, V. A., Troshkova, G. P., Mazurkova, N. A., and Shishkina, L. N. 2013. "Isolation, Characterization and Antiviral Properties of Biologically Active Substances of Higher Fungi of Western Siberia." Modern Problems of Science and Education 3. Accessed March 23, 2014. htpp://www.science-education.ru/pdf/2013/3/288.pdf. (in Russian)

[86] Wasser, S. P., and Weis, A. L. 1999. "Medicinal Properties of Substances Occurring in Higher Basidiomycetes Mushrooms: Current Perspectives (Review).” Int. J. of Med. Mushrooms 1: 31-62.

[87] Gurtsevich, V. E. 2008. "Human Tumors of Viral Origin: Mechanisms of Development and Prevention." The Russian Therapeutic Journal 7 (1): 8. (in Russian)

[88] Ko, H. H., Hung, C. F., Wang, J. P., and Lin, C. N. 2008. "Antiinflammatory Triterpenoids and Steroids from Ganoderma lucidum and G. tsugae." Phytochemistry 69: 234-9.

[89] Psurtseva, N. V., Teplyakova, T. V., and Kosogova, T. A. 2012. "Antiviral Properties of Higher Basidial Fungi." In Proceedings of the 3rd Congress of Russian Mycologists, 416-7. Modern Mycology in Russia. Vol 3. (in Russian)

[90] Vlasenko, V. A., Teplyakova, T. V., Mazurkova, N. A., Kosogova, T. A., Bardasheva, A.V., and Psurtseva, N. V. 2012. "The Study of Antiviral Activity of Medicinal Fungi of the Genus Phellinus s.l. in Western Siberia." Bulletin of the Altai State Agrarian University 4 (90): 29-31. (in Russian)

[91] Makarevich, E. V., Ibragimova, Zh. B., Kosogova, T. A., Kurskaya, O. G., Mazurkov, O. Yu., Ilyicheva, T. N., Teplyakova, T. V., and Mazurkova, N. A. 2012. "Immunogenic and Protective Properties of Extracts from Higher Fungi from a Group of Orders Gasteromycetes 
with Respect to Influenza A and B Viruses." Modern Problems of Science and Education 4. Accessed August, 15. 2012, http://www.science-education.ru/104-6823. (in Russian)

[92] Vlasenko, V. A., Vlasenko, A. V., An'kova, T. V., Kosogova, T. A., and Teplyakova, T. V. 2009. "Medicinal Fungi of the Genus Polyporus (Polyporus P. Micheli ex Adans, Polyporacea S.L.) in Novosibirsk Region.” Immunopathology, Allergology, Infectology 2: 168-9. (in Russian)

[93] Kosogova, T. A., Makarevich, E. V., Bardasheva, A. V., Mazurkova, N. A., and Teplyakova, T. V. 2012. "Promising Cultured Species of Wild Mushrooms of Southwestern Siberia Exhibiting Antiviral Activity against Influenza Virus." In Proceedings of the 8th International Conference on Problems of Forest Phytopathology and Mycology, 326-31. (in Russian)

[94] Yakimov, P. A. 1959. "General Biological and Chemical Characteristic of Chaga as Raw Material for Drug Production." In: Chaga and its Therapeutic Use. Leningrad, Medical Literature Publishers, 36-49. (in Russian)

[95] Shivrina, A. N., Lovyagina, E. V., and Platonova, E. G. 1959. "Chemical Composition of Chaga." In: Chaga and Its Therapeutic Use. Leningrad, Medical Literature Publishers, 55-61. (in Russian)

[96] Shivrina, A. N. 1965. Biologically Active Substances from Higher Fungi. Moscow: Leningrad. (in Russian)

[97] Shivrina, A. N. 1966. "Chemical Characteristics of Chaga Ingredients." In Biosynthesis Products from Higher Fungi and Their Use. Moscow-Leningrad, Nauka, 49-56. (in Russian)

[98] Babitskaya, V. G., Scherba, V. V., Ikonnikova, N. V., Bisko, N. A., and Mitropolskaya, N. Yu. 2002. "Melanin Complex from Medicinal Mushroom Inonotus obliquus (Pers.: Fr.) Pilat (Chaga) (Aphyllophoromycetidae)." Int. J. Med. Mushr. 4: 139-46.

[99] Kukulyanskaya, T. A., Kurchenko, N. V., Kurchenko, V. P., and Babitskaya, V. G. 2002. "Physicochemical Properties of Melanins Produced by Chaga in Nature and Under Cultivation." Applied Biochemistry and
Microbiology 38 (1): 68-72. (in Russian)

[100] Sysoeva, M. A., Kuznetsova, O. Yu., Gamayurova, V. S., Sukhanov, P. P., Ziyatdinova, G. K., and Budnikov, G. K. 2004. "The Study of the Sol of Aqueous Extracts of Chaga. III. The Effect of the Composition of Raw Material on the Yield of Extractive Substances from Chaga Aqueous Extracts." Chemistry of Vegetable Raw Material 4: 29-34. (in Russian)

[101] Yusoo, S., Yutaka, T., and Terazawa, M. 2001. "Chemical Constituents of Inonotus obliquus II: A New Triterpene, 21, 24-cyclopentalanosta-3b, 21, 25-triol-8-en.” J. Wood Sci. 47: 313-6.

[102] Babitskaya, V. G., Shcherba, V. V., and Gvozdkova, T. S. 2006. "New Biologically Active Supplements Based on the Deep Mycelium of Basidial Fungi." Advances in Medical Mycology 7: 178-80. (in Russian)

[103] Kovaleva, G. K., and Gromovykh, T. I. 2008. "Biological Properties and Productivity of the New Basidiomycete Strain G.A.-04 Ganoderma applanatum (Pers. ex Wallr.) Pat." Bulletin of Kransnoyarsk State Agrarian University 1: 70-5. (in Russian)

[104] Ananyeva, E. P., Gurina, S. V., and Sokolova, I. P. 2014. "Production of Basidiomycete Mycelium and Biological Activity of Its Components." Advances in Medical Mycology 12: 212-4. (in Russian)

[105] Antonenko, L. A., and Klechak, I. R. 2014. "Biochemical Composition of Mycelium of the Basidial Fungus Trametes versicolor." Advances in Medical Mycology 12: 215-6. (in Russian)

[106] Feofilova, E. P., Alekhin, A. I., Goncharov, N. G., Mysyakina, I. S., and Sergeeva, Ya. E. 2013. Fundamentals of Mycology and Development of Drugs from Fungal Mycelium. Moscow: National Academy of Mycology. (in Russian)

[107] Cohen, N., Cohen, J., Asatiani, M. D., Varshney, V. K., Yu, H. T., Yang, Y. C., Li, Y. H., Mau, J. L., and Wasser, S. P. 2014. "Chemical Composition and Nutritional and Medicinal Value of Fruit Bodies and Submerged Cultured Mycelia of Culinary-Medicinal Higher Basidiomycetes". Mushrooms International Journal of Medicinal Mushrooms 16 (3): 273-91. 